\title{
Socio-Cultural Determinants and the Moderating Effect of Gender in Adopting Sustainable Consumption Behavior among University Students in Iran and Japan
}

\author{
Sadegh Salehi ${ }^{1}\left({ }\right.$, Audronè Telešiené ${ }^{2, *}$ and Zahra Pazokinejad ${ }^{1,3}$ \\ 1 Department of Social Sciences, Research Group of Development Environment, University of Mazandaran, \\ Babolsar 4741613534, Iran; s.salehi.umz@gmail.com \\ 2 Civil Society and Sustainability Research Group, Faculty of Social Sciences, Arts and Humanities, Kaunas \\ University of Technology, 44249 Kaunas, Lithuania \\ 3 Iran National Science Foundation (INSF), Tehran 1439634665, Iran; zahrapazoki1464@gmail.com \\ * Correspondence: audrone.telesiene@ktu.lt
}

Citation: Salehi, S.; Telešienè, A.; Pazokinejad, Z. Socio-Cultural Determinants and the Moderating Effect of Gender in Adopting Sustainable Consumption Behavior among University Students in Iran and Japan. Sustainability 2021, 13, 8955. https://doi.org/10.3390/ su13168955

\section{Academic Editors:}

Genovaitè Liobikienè and

Hong-Youl Ha

Received: 15 June 2021

Accepted: 5 August 2021

Published: 10 August 2021

Publisher's Note: MDPI stays neutral with regard to jurisdictional claims in published maps and institutional affiliations.

Copyright: (c) 2021 by the authors. Licensee MDPI, Basel, Switzerland. This article is an open access article distributed under the terms and conditions of the Creative Commons Attribution (CC BY) license (https:// creativecommons.org/licenses/by/ $4.0 /)$.

\begin{abstract}
This article explores the underlying factors of sustainable consumption behavior. Survey data are employed to test the impacts of environmental attitude, knowledge, social awareness, perceived credibility of information sources, self-efficacy and gender on sustainable consumption patterns among samples of university students in Iran and Japan. This contributes to the scientific search for valid explanatory models that could be employed to foster lifestyle transformations towards sustainability. Our findings confirm positive relationship between self-efficacy, social awareness and sustainable consumption in both Japanese and Iranian samples. Other predicators did not have a consistent effect in both samples. This article also presents the results of moderated regression and discusses which impacts were moderated by gender. The discussion presents with interpretation of the findings and proposes possible alternative explanations.
\end{abstract}

Keywords: sustainable consumption; environmental behavior; sustainable development; university students

\section{Introduction}

Sustainability imperative has directed the development of many countries around the world [1]. The social indicators of well-being have been improving in the areas of public health, literacy and income in many countries, including Iran and Japan [2], while indicators of environmental quality have struggled to show signs of betterment. Air quality, pollution, soil erosion, drought, water scarcity, deforestation and unsustainable consumption have been increasing in many countries, pointing to the failure to decouple socio-economic development from its devastating negative impacts on the environment [3]. This unsure developmental pathway has triggered numerous social studies [4].

Environmental attitudes and behaviors, including sustainable consumption, are being researched widely across Europe, USA or OECD countries in general [5-7], but little is explored in other regions and countries [8]. We chose one more often researched case (from the above-mentioned group of countries) and one less researched case to advance the understanding of sustainable consumption factors. The Japanese case mainly serves as evaluation reference point, because it is a better researched case [9]. In addition, Iran presents a fertile case for furthering environmental studies $[10,11]$, with its distinctive culture and developmental pathway. Iran is currently suffering many problems including high pollution and increasing consumption rates. According to the statistics [12,13], water and energy consumption, time cost and employing production factors for production or provision of services is several times higher than the global standard. The study of sustainable consumption is a new arena in Iran and, given the worsening environmental 
situation, its importance becomes even greater. The research on social factors underpinning unsustainable consumption are scarce and very much needed in Iran [14]. Due to lack of representative national survey data on patterns of (un)sustainable consumption, the authors have collected data from Iranian students and contrasted them to the Japanese students' responses.

Scientific institutions, as higher education institutions, are centers for sustainable development education. A university campus is seen as a living laboratory of sustainability and is defined as a powerful agent of change $[15,16]$. University students serve as typical samples for analyzing environmental attitudes and behaviors $[17,18]$. Studying university students is sometimes seen as having advantages. An advantage is that the results are "controlled for age because most students fall in a fairly narrow age range, and the age group used to be more sensitive to environmental issues" [19] (p. 42). Environmental attitudes and behaviors of university students have already been studied in many countries, e.g., in Turkey [20], UK [21], Brazil [22] and Iran [23].

The general aim of this paper is to examine the sustainable consumption factors of Iranian students (also testing the moderating effect of gender) and to contrast these to the consumption patterns of Japanese students. Japan ranks 13th out of 34 countries based on all dimensions of the Sustainable Development Goals index [24]. This country is a leader on goal 12, which calls for sustainable consumption and production patterns. With 9.5 tons per capita, Japan has the lowest domestic material consumption among the OECD countries [24]. However, according to a World Bank report [25], Iran produces approximately 14.7 million tons of municipal waste per year. This increasing trend is caused by the lifestyle and patterns of consumption, especially fast food, packaged foods, drinking water and beverages. Research shows that $89 \%$ of household waste in Iran is food waste [26]. The amount of energy consumption from 1967 to 2012 increased by $7.3 \%$ yearly, while in this period, on average, Iran's GDP grew by 3.2\% annually, signifying a rise in energy intensity in Iran [27]. Good governance, civil partnership and informed and committed citizens are the ultimate factors needed to improve sustainability of production and consumption. The extension of the patterns of sustainable consumption requires the establishment of the sustainable lifestyle and attitudes and beliefs related with it. This paper has two specific tasks: (a) analyzing and comparing the correlates of sustainable consumption in Iranian and Japanese university students' samples; (b) testing the moderation effect of gender in both samples.

\section{Conceptual Framework and Hypotheses}

Sustainability studies emphasize sustainable consumption in the face of global climate changes and in an attempt to mitigate global environmental degradation. The concept of sustainable consumption was first introduced into environmental policy debates by the AGENDA 21 document accepted at the UN Conference on Environment and Development in Rio de Janeiro. Chapter 4 of the document considers changing established consumer patterns and structures to be a fundamental precondition for moving towards sustainable development [28]. Transition to a sustainable society would require transformation of values-distancing from consumerism and approaching post-consumerism [29]. Evidently, many factors are at play in building a sustainable consumption pattern.

Sustainable consumption (SC) is defined in this article as a private-sphere environmentally significant behavior [6]. Environmentally significant behavior is determined by specific environmental attitudes and beliefs about the environment that, in turn, are preceded by general views on the vulnerability of nature and the environmental system [30] (p. 456). Many studies show that sustainable consumers have positive environmental attitudes and beliefs [7,18,31-33]. Environmental attitude (EA) is a set of beliefs, concerns and motivations that individuals have towards the environment and environmental problems.

Hypothesis 1. Environmental attitudes correlate significantly with sustainable consumption. 
Each individual has parallel roles of a consumer and a citizen [34]. Consumers are the ones who actually buy products and services. The consequence of consumers' insatiable tendencies is bootless consumption and waste of resources that also result in deepening manifold forms of injustice within and among societies. In contrast, the role of a citizen relates to caring for the general well-being of societies. A sustainable society would emphasize a citizen role more than a consumer one [34]. Citizens in a sustainable society are envisaged as knowledgeable. The impact of knowledge on environmental behaviors and SC is not straightforward. Some research, e.g., in Malaysia [35], found that knowledge had a positive relationship with environmental participation and behaviors. Research conducted in US [36] indicated that pro-environmental attitudes significantly predicted pro-environmental behaviors and that knowledge was a significant moderator for the relationship. Research conducted in Korea [37] and in UK [38] found that EK and knowledge of climate change has a positive effect on environmentally significant behavior. This leads us to the second hypothesis:

Hypothesis 2. Knowledge of climate change significantly correlates with sustainable consumption.

Reliable information is crucial in the process of educating the public and engaging ordinary citizens for the protection of the environment [14,39]. Environmental groups, governments, mass media and universities provide information about the environment. If citizens trust an information source, they internalize the necessary information about environmental issues and possibly take responsible environmental behavior accordingly. Perceived credibility of the information sources (IS) has an important role while explaining environmental behavior [40]. Trustworthy environmental information sources provide awareness of environmental issues and understanding of public and scientific policies related to the environment and is one of the prerequisites of participation in environmental policies and programs [41]. The third hypothesis of this study is stated as follows:

Hypothesis 3. Perceived credibility of informational sources significantly correlates with sustainable consumption.

Social consciousness or social awareness (SA) is defined as the awareness of the social situation shared by a group or a community in a common environment, which can be physical, virtual or both [42]. For many researchers, awareness about issues affecting the community or raising social consciousness has always been a precursor to social movement [43]. In a society with low SA, the establishment and development of social trust and a sense of harmony is difficult. Fair distribution of resources affects SA and induces a sense of solidarity among people. High social inequality creates a feeling of powerlessness, which reduces individual public and voluntary participation. Value-belief-norm theory defines powerlessness as a perception that one has no power to alter an outcome by taking an action, where people think that taking action will make no difference to the outcome [44] (p. 752). A positive relationship between SA and trustworthy environmental informational sources has been already found for Iranian and Czech students [14]. The same study showed that female students had reported greater social consciousness than male students, yet the Iranian female students' SA was greater than that of Czech female students. Based on previous studies, the fourth hypothesis of this research is drawn as:

Hypothesis 4. Social awareness significantly correlates with sustainable consumption.

In recent decades, research on the role of self-efficacy (SE) in explaining environmental behavior has gained momentum $[39,45,46]$. SE can be defined as a strong belief in one's capacity to organize and guide the courses of action required to tackle certain situations in the immediate future [46] (p. 659). In relation to climate change, SE has been defined as the perceived ability to influence climate changes outcomes, to induce others to behave in ways that minimize human sources of climate changes and encourage the acceptance 
of climate changes as a human responsibility [39]. As an important construct, SE relates to an individual's perception of his/her ability to successfully perform the recommended behaviors [45]. Interestingly, SE is an ingredient in the empowerment variables [47] and in the belief that one can have an impact on environmental issues. Since previous studies considered the SE variable as an effective factor on sustainable consumption, the following hypothesis is extracted:

Hypothesis 5. Self-efficacy significantly correlates with sustainable consumption.

Studies show that environmental attitudes, behaviors and consumption are genderspecific and that "women tend to have less resource-intensive (and therefore more sustainable) lifestyles [... ] while men's consumption patterns and ecological footprint are usually greater than women's" [48] (p. 164). Gender moderates the effects of predictors. A moderator variable may influence the degree of relationship between two variables which would be evidenced by systematic variation in either a correlation coefficient or the squared correlation coefficient in a regression context. Alternatively, a moderator variable may influence the form of relationship created if there were systematic variations in regression coefficients [49].

Hypothesis 6. The effect of predictors on the sustainable consumption are moderated by gender.

According to the above stated hypotheses, we expect that students who are ecocentric, have at least moderate EK, put credibility into available information sources, have higher SA and stronger feeling of SE would engage more responsibly with sustainable consumption. Furthermore, we are set to explore how gender will moderate the effects of the listed predictors (see Figure 1).

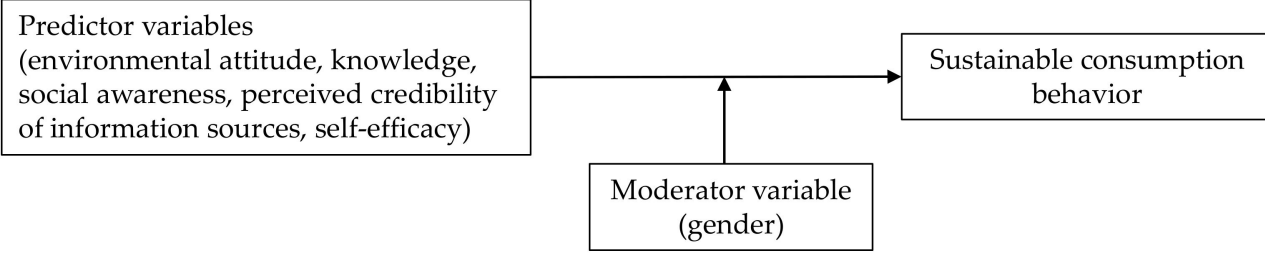

Figure 1. Proposed theoretical model.

\section{Materials and Methods}

The surveys of university student groups in Japan and Iran were conducted in November-December 2016. Written questionnaires (paper-and-pencil) were chosen as a method of administering the surveys. The survey was conducted in two faculties of two different universities. First, there was a sample from the Faculty of Social Sciences and Humanities of Mazandaran University (Iran), which included the departments of Social Sciences, Educational Sciences, Urban Planning, Persian Language and Literature and Tourism Management. Population of the Iranian case included 850 students. In this case, the calculated sample size was 271 (we employed the Cochran formula). Of these, 198 valid questionnaires were obtained. The second sample was from the Faculty of Political Studies in Chuo University (Japan), which offers curriculum in political sciences and cross-cultural studies. The faculty included the departments of Legal Studies, Social Sciences, Business Management and Administration, Cross-Cultural and Regional Studies, Media, Information Technology and Languages. Of 1172 students, 212 were selected for the survey. Of these, 199 valid questionnaires were obtained. For both the Iranian and Japanese cases, we employed cluster sampling with student groups in classes as sampling units. The response rate was $93.9 \%$ for Japan and $73 \%$ for Iran. Iranian students might have had a lower response rate due to survey fatigue, because at the time of the survey, other studies were being conducted on campus. The final sample consisted of 199 respondents 
from Chuo University in Japan and 198 students from Mazandaran University in Iran. The Iranian sample consisted of $64.6 \%$, and the Japanese sample of $52.3 \%$ female respondents (calculated from the actual number of responses).

\section{Instrument and Measures}

To measure sustainable consumption (SC), we developed 10 statements on a fourpoint Likert scale with answers ranging from always to never $(1=$ never, $2=$ sometimes, $3=$ rarely, $4=$ always). The minimum number of total points was 10 and the maximum was 40 . The scale had good internal consistency ( $\alpha=0.74$, Iran; $\alpha=0.84$, Japan). Five statements (use of public transport, sorting dry waste from wet waste, buying electrical goods with energy labels, limiting the purchase of luxury goods and purchasing goods with environmental health labels) have been adapted from previous research [50].

The NEP scale [51] was used to measure environmental attitudes (EA). The NEP addresses four aspects of an environmental worldview - the realization of limits to growth, anti-anthropocentrism, belief in the fragility of the balance of nature, rejection of human exceptionalism - with three statements for each. Based on the scale, attitudes were measured with 15 statements on five-point Likert scales, ranging from $1=$ strongly disagree, $2=$ disagree, $3=$ undecided, $4=$ agree, $5=$ strongly agree. The minimum and maximum points were scored on the NEP scale as $\min =15$ and $\max =75$. Among these fifteen statements, there are nine positively worded (pro-environment) statements and three negatively worded statements. Agreement with nine positively worded statements results in higher measures, while measures of the three negatively narrated statements are reversed so that disagreement with them results in lower measures. In this study, the scale had moderately low internal consistency ( $\alpha=0.61$, Iran; $\alpha=0.64$, Japan).

Knowledge of climate change (KCC), another independent variable, was measured through a fifteen-item block. It includes questions on the causes, consequences and potential solutions to global climate changes and practical environmental knowledge that enables individual and collective action [52]. To measure this variable, we used nine statements related to global warming and the greenhouse effect and six statements related to ozone depletion [21]. Each set of statements included four that covered basic scientific knowledge and five that addressed the applications of that knowledge. Each statement was measured with five-point Likert type scales ranging from strongly disagree to strongly agree $(1=$ strongly disagree, $5=$ strongly agree). The range of change in scores of this variable fluctuates between 15 and 75 . In this study, the results showed that the scale had acceptable internal consistency ( $\alpha=0.77$, Japan; $\alpha=0.76$, Iran).

To measure the perceived credibility of information sources (IS), we used five items related to informational sources [39]. Each item was measured on five-point scales ranging from strongly disagree to strongly agree. ( $1=$ strongly disagree, $5=$ strongly agree). The minimum and maximum points that can be scored on information sources are 5 and 25, respectively. The scale had acceptable internal consistency $(\alpha=0.76$, Japan; $\alpha=0.71$, Iran) (see Table 1).

Self-efficacy (SE) was the independent variable in this study and was measured in Likert scale format $(1=$ strongly disagree, $5=$ strongly agree) [53]. The minimum score was 5 and the maximum score was 20.

Social awareness (SA) was also measured using a Likert-type response format $(1=$ strongly disagree, $5=$ strongly agree). The minimum score was 5 and the maximum score was 25 . Higher scores indicated greater awareness. In this study, the final scale had moderately low internal consistency for Japan $(\alpha=0.61)$ and the scale had high internal consistency for Iran $(\alpha=0.74)$.

Factor analysis was used to assess internal consistency and model fit to the data. The instrument for gathering data employed in this study was a closed self-administrated questionnaire. The reliability of the questionnaire was calculated using Cronbach's alpha test for the variables measured by the Likert scale $(0.61<\alpha<0.84)$. Table 1 shows the constructs and items, and their factor loadings after rotation. 
Table 1. Constructs and items (Iran and Japan).

\begin{tabular}{|c|c|c|c|}
\hline Constructs & Items & Factor Loading (Japan) & Factor Loading (Iran) \\
\hline \multirow{10}{*}{$\begin{array}{l}\text { Sustainable } \\
\text { consumption } \\
\text { (SC) }\end{array}$} & The use of public transport. & 0.59 & 0.57 \\
\hline & The use of bicycles. & 0.65 & 0.60 \\
\hline & Sorting dry waste from wet waste. & 0.40 & 0.53 \\
\hline & The use of energy efficient light bulbs. & 0.56 & 0.56 \\
\hline & Efficient use of water in bathing. & 0.44 & 0.43 \\
\hline & Reducing meat consumption. & 0.46 & 0.42 \\
\hline & Increased consumption of fruits and vegetables organic. & 0.56 & 0.52 \\
\hline & Buy electrical goods with energy labels. & 0.68 & 0.72 \\
\hline & Limiting the purchase of luxury goods. & 0.48 & 0.45 \\
\hline & Purchase goods with environmental health labels. & 0.69 & 0.62 \\
\hline Bartlett's Test $=293.114$, Sig $=0.000($ Ir $)$ & & Mean $=2.67$ & Mean $=2.90$ \\
\hline Bartlett's Test $=568.206$, Sig $=0.000(\mathrm{Ja})$ & & $\mathrm{SD}=0.84$ & $\mathrm{SD}=1.06$ \\
\hline \multirow{8}{*}{$\begin{array}{l}\text { Environmental Attitudes } \\
\text { (NEP) }\end{array}$} & $\begin{array}{l}\text { We are approaching the limit of the number of people the } \\
\text { earth can support. }\end{array}$ & 0.55 & 0.50 \\
\hline & $\begin{array}{l}\text { When humans interfere with nature, it often produces } \\
\text { disastrous consequences. }\end{array}$ & 0.44 & 0.45 \\
\hline & Humans are severely abusing the environment. & 0.57 & 0.41 \\
\hline & $\begin{array}{l}\text { The earth has plenty of natural resources if we just learn how } \\
\text { to develop them. }\end{array}$ & 0.58 & 0.66 \\
\hline & Plants and animals have as much right as humans to exist. & 0.75 & 0.66 \\
\hline & $\begin{array}{l}\text { The balance of nature is strong enough to cope with the } \\
\text { impacts of modern industrial nations. }\end{array}$ & 0.42 & 0.41 \\
\hline & The earth has only limited room and resources. & 0.41 & 0.45 \\
\hline & $\begin{array}{l}\text { If things continue on their present course, we will soon } \\
\text { experience a major ecological disaster. }\end{array}$ & 0.47 & 0.51 \\
\hline Bartlett's Test $=113.822$, Sig $=0.000($ Ir $)$ & & Mean $=4.06$ & Mean $=3.96$ \\
\hline Bartlett's Test $=140.852, \mathrm{Sig}=0.000(\mathrm{Ja})$ & & $\mathrm{SD}=0.95$ & $\mathrm{SD}=1.02$ \\
\hline \multirow{9}{*}{$\begin{array}{l}\text { Knowledge of climate changes } \\
\text { (KCC) }\end{array}$} & $\begin{array}{l}\text { Carbon dioxide in the atmosphere contributes to the global } \\
\text { greenhouse effect. }\end{array}$ & 0.55 & 0.48 \\
\hline & Exacerbation of greenhouse effect causes global warming. & 0.67 & 0.62 \\
\hline & $\begin{array}{l}\text { Scientists predict that the burning of fossil fuels, especially } \\
\text { coal, will enhance the greenhouse effect. }\end{array}$ & 0.50 & 0.56 \\
\hline & $\begin{array}{l}\text { Without the layer of ozone in the atmosphere, life on earth is } \\
\text { endangered. }\end{array}$ & 0.52 & 0.63 \\
\hline & $\begin{array}{l}\text { Scientists argue that large amounts of ozone gas in the } \\
\text { atmosphere increased ultraviolet radiation on the earth's } \\
\text { surface. }\end{array}$ & 0.48 & 0.73 \\
\hline & CFCs, are the most serious threat to the ozone layer. & 0.55 & 0.45 \\
\hline & $\begin{array}{l}\text { Extinction of tropical rain forests likely intensifies the global } \\
\text { greenhouse effect. }\end{array}$ & 0.47 & 0.57 \\
\hline & $\begin{array}{l}\text { Greater exposure to ultraviolet radiation generally increases } \\
\text { the risk of contracting skin cancer and developing cataracts of } \\
\text { the eye. }\end{array}$ & 0.62 & 0.48 \\
\hline & $\begin{array}{l}\text { Scientists have yet to find evidence that suggests that } \\
\text { stratospheric ozone levels are declining over the Iran }\end{array}$ & 0.58 & 0.56 \\
\hline $\begin{array}{l}\text { Bartlett's Test }=286.935, \mathrm{Sig}=0.000(\mathrm{Ir}) \\
\text { Bartlett's Test }=321.689, \mathrm{Sig}=0.000(\mathrm{Ja})\end{array}$ & & Mean $=3.97 \mathrm{SD}=0.90$ & $\begin{array}{l}\text { Mean }=3.09 \\
\mathrm{SD}=1\end{array}$ \\
\hline \multirow{5}{*}{$\begin{array}{l}\text { Information Sources } \\
\text { (IS) }\end{array}$} & I trust the governmental information about climate changes. & 0.48 & 0.58 \\
\hline & $\begin{array}{l}\text { I trust the information the non-governmental agencies on } \\
\text { climate changes. }\end{array}$ & 0.54 & 0.45 \\
\hline & $\begin{array}{l}\text { In my opinion, scientists have accurate understanding of } \\
\text { global warming and climate changes. }\end{array}$ & 0.60 & 0.61 \\
\hline & $\begin{array}{l}\text { In my opinion, scientists can reduce our concern to the risk of } \\
\text { global warming and climate changes. }\end{array}$ & 0.63 & 0.53 \\
\hline & $\begin{array}{l}\text { Environmental groups have accurate information about } \\
\text { climate changes. }\end{array}$ & 0.58 & 0.98 \\
\hline Bartlett's Test $=177.183$, Sig $=0.000$ (Ir) & & Mean $=2.93$ & Mean $=3.15$ \\
\hline Bartlett's Test $=248.995, \mathrm{Sig}=0.000(\mathrm{Ja})$ & & $\mathrm{SD}=1.02$ & $\mathrm{SD}=1.1$ \\
\hline \multirow{4}{*}{$\begin{array}{l}\text { Self-efficacy } \\
\quad(\mathrm{SE})\end{array}$} & $\begin{array}{l}\text { I am prepared to change my behavior in a way that limits the } \\
\text { climate changes. }\end{array}$ & 0.57 & 0.63 \\
\hline & $\begin{array}{l}\text { In my opinion, my activities do not have much impact on } \\
\text { climate changes. }\end{array}$ & 0.63 & 0.68 \\
\hline & $\begin{array}{l}\text { Human begins are responsible for global warming and } \\
\text { climate changes. }\end{array}$ & 0.43 & 0.57 \\
\hline & I'm trying to make others aware of the global warming risks. & 0.59 & 0.57 \\
\hline Bartlett's Test $=164.116$, Sig $=0.000($ Ir $)$ & & Mean $=3.21$ & Mean $=3.51$ \\
\hline Bartlett's Test $=142.857, \mathrm{Sig}=0.000(\mathrm{Ja})$ & & $\mathrm{SD}=1.16$ & $\mathrm{SD}=1.2$ \\
\hline \multirow{6}{*}{$\begin{array}{l}\text { Social } \\
\text { awareness } \\
\text { (SA) }\end{array}$} & $\begin{array}{l}\text { In my opinion, in the society, people's income levels should } \\
\text { be close. }\end{array}$ & 0.45 & 0.53 \\
\hline & The society consists by mutual trust. & 0.43 & 0.59 \\
\hline & $\begin{array}{l}\text { Most people in the community are only thinking about } \\
\text { themselves. }\end{array}$ & 0.60 & 0.54 \\
\hline & $\begin{array}{l}\text { The behavior of the individual in the community is such that } \\
\text { others can influence it. }\end{array}$ & 0.44 & 0.46 \\
\hline & A society grows that people have devotion and sacrifice. & 0.56 & 0.43 \\
\hline & In general, our society is an unequal one. & 0.63 & 0.41 \\
\hline Bartlett's Test $=321.689$, Sig $=0.000(\mathrm{Ja})$ & & Mean $=3.11$ & Mean $=3.88$ \\
\hline Bartlett's Test $=92.394$, Sig $=0.000($ Ir $)$ & & $\mathrm{SD}=1.11$ & $\mathrm{SD}=1$ \\
\hline
\end{tabular}


The Kaiser-Meyer-Olkin (KMO) test shows that data are suitable for factor analysis. Mean and standard deviation were calculated based on these factors. The 7 factor loadings of the new ecological paradigm (NEP) for both groups were less than 0.30 and excluded from the analysis. Moreover, the 6 items of the knowledge of climate change (KCC) for both groups were excluded from the analysis because their factor loadings were less than 0.30 . The value of the KMO index of sustainable consumption construct is 0.754 (Iran) and 0.824 (Japan), NEP scale is 0.721 (Japan) and 0.635 (Iran), knowledge of climate change is 0.771 (Japan) and 0.801 (Iran), information sources is 0.752 (Japan) and 0.641 (Iran), self-efficacy is 0.642 (Japan) and 0.737 (Iran) and social awareness is 0.715 (Japan) and 0.810 (Iran), which indicates the ability of the data to use the factor analysis technique. The significance level of the Bartlett test is 0.000, which indicates the ability to extend factor analysis to the total population.

\section{Results}

Analysis of factors influencing sustainable consumption is presented in two parts. First, the relationships between independent variables (IV) and dependent variable (DV) are examined using Pearson correlation analysis, and then using moderating regression, the relationship between the IV and DV is interpreted according to the moderating role of gender. Tables 2 and 3 compares correlations between EA, KCC, IS, SE and SA as independent variables and SC as the dependent variable.

Table 2. Correlation (Pearson $r$ ) between independent and dependent variables (Japan).

\begin{tabular}{ccccccc}
\hline Variable & SC & EA & KCC & IS & SE & SA \\
\hline SC & 1 & & & & & \\
EA & $-0.149^{*}$ & 1 & & & \\
KCC & $-0.179^{*}$ & $0.559^{* *}$ & 1 & 1 & 1 \\
IS & $0.467^{* *}$ & -0.066 & 0.097 & 0.131 & $0.533^{* *}$ & $0.534^{* *}$ \\
SE & $0.514^{* *}$ & 0.046 & 0.068 & 0.54 & 1 \\
SA & $0.532^{* *}$ & 0.006 & . & & \\
\hline
\end{tabular}

Note: $\mathrm{N}=198 . \mathrm{SC}=$ sustainable consumption; $\mathrm{EA}=$ environmental attitudes; $\mathrm{KCC}=$ knowledge about climate change; IS = perceived credibility of information sources; $\mathrm{SE}=$ self-efficacy; $\mathrm{SA}=$ social awareness. ${ }^{*} p<0.05,{ }^{* *} p<0.001$.

Table 3. Correlation (Pearson r) between independent and dependent variables (Iran).

\begin{tabular}{ccccccc}
\hline Variable & SC & EA & KCC & IS & SE & \\
\hline SC & 1 & & & & \\
EA & $0.206^{*}$ & 1 & & & \\
KCC & 0.132 & $0.341^{* *}$ & $0.159^{*}$ & $0.356^{* *}$ & 1 & 1 \\
IS & 0.065 & $0.389^{* *}$ & $0.628^{* *}$ & $0.410^{* *}$ & $0.0313^{* *}$ \\
SE & $0.176^{*}$ & $0.246^{* *}$ & $0.277^{* *}$ & 0.071 & 1 \\
SA & $0.365^{* *}$ & SA & \\
\hline
\end{tabular}

Note: $\mathrm{N}=199 . \mathrm{SC}=$ sustainable consumption; $\mathrm{EA}=$ environmental attitudes; KCC = knowledge about climate change; IS = perceived credibility of information sources; $\mathrm{SE}=$ self-efficacy; $\mathrm{SA}=$ social awareness. ${ }^{*} p<0.05,{ }^{* *} p<0.001$.

In the case of Japan, EA and KCC have a weak and negative correlation with SC. In contrast, SE, IS and SA have a positive and moderate correlation with SC.

In the case of Iran, all variables correlate positively with SC, except KCC and IS.

The interesting finding here is that the knowledge variable was insignificant (Iran) and negatively correlated to the sustainable consumption (Japan). This represents the phenomenon of the knowledge-behavior gap [5] that has also been found in, e.g., Malaysia [54], where environmental knowledge was found insignificant for explaining green purchase intentions.

To test the hypothesis of whether gender moderates the relationship between the above presented predicators and sustainable behavior, a hierarchical multiple regression analyses were conducted. In the first step, EA, KCC, SE, IS, SA and gender were included 
as the predicators. These variables accounted for a significant amount of SC variance in both the Japanese $\left(R^{2}=0.43, F=25.94, p<0.00\right)$ and Iranian $\left(R^{2}=0.11, F=4.92, p<\right.$ 0.00 ) samples (see Table 4 ). To avoid high multicollinearity with the interaction term, the variables were centered.

Table 4. Summary model for the moderated regressions.

\begin{tabular}{|c|c|c|c|c|c|c|c|c|c|c|c|c|}
\hline \multicolumn{7}{|c|}{ Japan } & \multicolumn{6}{|c|}{ Iran } \\
\hline Model & $\begin{array}{c}\mathbf{R} \\
\text { Square }\end{array}$ & $\mathbf{R}^{2}$ & $\begin{array}{l}\text { R Square } \\
\text { Change }\end{array}$ & F & $\begin{array}{c}\text { F } \\
\text { Change }\end{array}$ & $\begin{array}{c}\text { Sig. F } \\
\text { Change }\end{array}$ & $\begin{array}{c}\mathbf{R} \\
\text { Square }\end{array}$ & $\mathbf{R}^{2}$ & $\begin{array}{c}\text { R Square } \\
\text { Change }\end{array}$ & F & $\begin{array}{c}F \\
\text { Change }\end{array}$ & $\begin{array}{c}\text { Sig. F } \\
\text { Change }\end{array}$ \\
\hline 1 & 0.45 & 0.43 & 0.45 & 25.94 & 25.94 & 0.00 & 0.13 & 0.11 & 0.13 & 4.92 & 4.92 & 0.000 \\
\hline 2 & 0.53 & 0.51 & 0.08 & 19.51 & 6.93 & 0.00 & 0.23 & 0.18 & 0.09 & 4.94 & 4.41 & 0.001 \\
\hline
\end{tabular}

Next, the interaction terms between the predicators and gender were added to the regression model, which accounted for a significant proportion of the variance in sustainable consumption both in Japanese and Iranian samples. Variables entered in moderated regression explained $53 \%$ of the variance in SC in the case of Japan, and $23 \%$ of variance in the case of Iran. Gender explained an additional $8 \%$ and $9 \%$ of variance in SC for Japan and Iran, respectively. The results are significant for both groups (see Table 4). The ANOVA indicated that the model as a whole is significant for both Japan $(\mathrm{F}=6.93, p<0.00)$ and $\operatorname{Iran}(\mathrm{F}=4.94, p<0.001)$.

Table 5 shows the results of the enter method regression analysis to predict $\mathrm{SC}$. The regression showed that gender did moderate the relations between KCC, IS, SA and SC in the case of Japan $(p<0.005)$; moreover, and in the case of Iran, it did moderate these relationships between EA and SA with SC $(p<0.005)$. In the case of Japan, the estimated difference in regression weights between male and female subgroups is 0.69 for KCC, -0.83 for IS and -0.51 for SA. In the case of Iran, this difference between male and female subgroups shows no difference ( -0.003 for EA and SA). Furthermore, in the case of Japan, the difference in intercept between both subgroups at mean of KCC, IS and SA is -0.45 , while in the case of Iran, this difference between two subgroups at mean of EA and SA is 6.98. Finally, in the case of Japan, the simple slope for gender due to the KCC is -1.29 , IS (1.49) and SA (1.06); in the case of Iran, this simple slope due to EA is 0.57 and SA is 0.65. 
Table 5. Summary of regression analysis.

\begin{tabular}{|c|c|c|c|c|c|c|c|c|c|c|c|c|c|}
\hline Model & Variables & $\begin{array}{l}\text { Unstandardized } \\
\text { Coef. B (Japan) }\end{array}$ & $\mathrm{SE}$ & $\begin{array}{c}\text { Standardized Coef. } \\
\text { B (Japan) }\end{array}$ & Sig. & $\begin{array}{l}\text { Collinearity Statistics } \\
\text { Tolerance (Japan) }\end{array}$ & VIF & $\begin{array}{l}\text { Unstandardized } \\
\text { Coef. B (Iran) }\end{array}$ & SE & $\begin{array}{l}\text { Standardized } \\
\text { Coef. B (Iran) }\end{array}$ & Sig. & $\begin{array}{l}\text { Collinearity Statistics } \\
\text { Tolerance (Iran) }\end{array}$ & VIF \\
\hline \multirow{6}{*}{1} & EA & 0.004 & 1.06 & -0.13 & 0.02 & 0.75 & 1.32 & 0.14 & 0.86 & 0.13 & 0.05 & 0.79 & 1.26 \\
\hline & KCC & -0.43 & 0.07 & -0.23 & 0.00 & 0.71 & 1.10 & 0.06 & 0.78 & -0.009 & 0.72 & 0.53 & 1.86 \\
\hline & $\mathrm{SE}$ & 0.63 & 0.12 & 0.30 & 0.00 & 0.58 & 1.70 & -0.02 & 0.12 & 0.01 & 0.78 & 0.49 & 2.03 \\
\hline & IS & 0.42 & 0.10 & 0.20 & 0.01 & 0.55 & $\begin{array}{l}1.79 \\
\text {. }\end{array}$ & 0.01 & 0.071 & 0.02 & 0.65 & 0.78 & 1.27 \\
\hline & SA & 0.48 & 0.10 & 0.30 & 0.00 & 0.53 & 1.85 & 0.23 & 0.15 & 0.36 & 0.00 & 0.79 & 1.26 \\
\hline & Gender & -0.56 & 0.66 & -0.05 & 0.33 & 0.94 & 1.06 & -1.35 & 0.56 & -0.16 & 0.02 & 0.90 & 1.10 \\
\hline \multirow{10}{*}{2} & EA & 0.15 & 0.30 & 0.09 & 0.59 & 0.63 & 1.57 & 0.57 & 0.18 & 0.54 & 0.002 & 0.76 & 1.30 \\
\hline & KCC & -1.29 & 0.30 & -0.75 & 0.00 & 0.66 & 1.50 & 0.23 & 0.16 & 0.33 & 0.16 & 0.60 & 1.65 \\
\hline & $\mathrm{SE}$ & 0.99 & 0.39 & 0.50 & 0.01 & 0.66 & 1.51 & -0.37 & 0.33 & -0.28 & 0.26 & 0.68 & 1.45 \\
\hline & IS & 1.49 & 0.39 & 0.75 & 0.00 & 0.70 & 1.49 & 0.39 & 0.27 & 0.34 & 0.15 & 0.82 & 1.87 \\
\hline & Gender & -0.45 & 0.67 & -0.36 & 0.73 & 0.59 & 1.13 & 6.98 & 2.58 & 0.86 & 0.00 & 0.93 & 1.07 \\
\hline & Gender*EA & -0.069 & 0.12 & -0.005 & 0.92 & 0.75 & 1.33 & -0.003 & 0.001 & -0.37 & 0.019 & 0.85 & 1.17 \\
\hline & Gender*KCC & 0.69 & 0.14 & 0.13 & 0.02 & 0.71 & 1.39 & -0.016 & 0.011 & -0.31 & 0.15 & 0.69 & 1.44 \\
\hline & Gender*SE & -0.35 & 0.25 & -0.04 & 0.45 & 0.59 & 1.67 & -0.025 & 0.017 & 0.27 & 0.23 & 0.62 & 1.59 \\
\hline & Gender*IS & -0.83 & 0.22 & -0.13 & 0.04 & 0.54 & 1.83 & 0.26 & 0.022 & -0.31 & 0.14 & 0.86 & 1.15 \\
\hline & Gender*SA & -0.51 & 0.21 & -0.20 & 0.00 & 0.53 & 1.86 & -0.003 & 0.001 & -1.25 & 0.002 & 0.83 & 1.19 \\
\hline
\end{tabular}




\section{Discussion}

This paper examined the relationships of environmental attitude (EA), knowledge of climate changes (KCC), social awareness (SA), perceived credibility of information sources (IS) and self-efficacy (SE) with sustainable consumption (SC) patterns among Iranian and Japanese university students.

Our findings showed a positive significant relationship between SA and SE in both the Iranian and Japanese samples. Therefore, our data confirm Hypotheses 4 and 5. Our findings are consistent with Salehi et al. [14], who also proved that SA has positive effect on sustainable consumption behavior. Similar to our findings, Hanss and Böhm [55] in Norway and Phipps et al. [56] in Australia proved that consumers' self-efficacy had a positive impact on sustainable consumption behavior. Through structural equation modelling, Tabernero and Hernández [46] in Cordoba, Spain, found that self-efficacy is pertinent to the recycling behavior. According to these studies, self-efficacy is associated with recycling behavior by enhancing intrinsic motivation. In fact, self-efficacy can develop sustainable consumption behaviors when individuals have direct control over their own behaviors (this includes consumption). Further studies prove that SE does not only have significant direct effects, but also might serve as a significant moderator variable. For example, Meinhold and Malkus [36] proved that in the US, the relationship between environmental attitudes and behavior is stronger among adolescences with high levels of self-efficacy. Further studies could employ self-efficacy as a moderator variable.

Environmental attitudes were significant correlates in both the Iranian and the Japanese samples, but it was negatively related to SC in Japan and positively in Iran. Technically, our results mean that Hypothesis 1 is confirmed. Yet, it also points to the need to further research the conditions which determine the direction of this variable's influence on pro-environmental behaviors.

We obtained conflicting results for the influence of knowledge and perceived credibility of the information sources on SC in Japan and Iran. Knowledge had a significant negative effect and IS had a significant positive effect on SC in the Japanese sample, but both independent variables were non-significant in the Iranian sample. Therefore, we only partially confirmed Hypotheses 2 and 3. Further research is needed to explain the particular contexts of Iran, where typical correlates of pro-environment behavior are not always significant.

When looking at our results of IS as predictor of SC, our findings are consistent with the findings achieved by Kong, Salzmann, Steger and Ionescu-Somers [57] as well as by Mont and Bleischwitz [58], who found that the perceived credibility of information sources has positive impacts on sustainable consumption behavior.

Many studies find that EA is positively related to SC; e.g., Gilg et al. [33] found that environmental attitudes have a positive effect on sustainable consumption in the UK and China. The results obtained by Meinhold and Malkus [36] in the US indicated that pro-environmental attitudes significantly predicted pro-environmental behaviors and that environmental knowledge was a significant moderator for the relationship between environmental attitudes and environmental behaviors. Osman et al. [59] discovered a significant link between environmental knowledge, attitude and behavior, and found that with more comprehensive knowledge in students, environmental attitude is enhanced. In Korea, Moon et al. [37] found that environmental knowledge has a positive effect on environmentally significant behavior, but the findings of Chekima et al. [54] demonstrate that environmental knowledge does not have a significant influence on green purchase intentions. In contrast, cultural values and environmental advertising have a significant relationship with it.

In terms of Hypothesis 6, our findings show that the tested predictors' effects are moderated by gender in both the Japanese and Iranian samples. On average, Japanese female students have greater knowledge of climate changes and this was a more important SC factor for them than for the male students. In contrast, perceiving environmental information sources as credible is more important for Japanese male students than female 
students. Finally, for Japanese male students, social awareness was a little more important than for their female counterparts. In the case of Iran, having positive environmental attitude and social awareness is more important for Iranian male students than for their female counterparts. The concept of social roles would point to the different gender positions within societies as an explanation of our results [60] (p.71). Gendered social norms and social roles mean different social expectations, experiences and competencies that develop as a result of being socialized to perform these different roles. The gender-moderated effects were different for the Japanese and the Iranian samples. This finding, together with the finding of differences in typical correlates of pro-environment behaviors among the Japanese and Iranian samples, asks for further research of more tuned explanatory models. Possible future explanatory models might look at influences beyond people's volitional control [61], such as situational influences of economic constraints, social pressures or lack of behavioral alternatives. Adding external factors such as green product availability and perceived consumer effectiveness might improve explanatory models [62] (p. 125). Looking at the perceived consumer effectiveness might be another option for the future research, as it has been shown to be particularly important as a direct predictor of socially conscious behavior. For example, Failla and Gopalakrishna [63] found that perceived consumer effectiveness had a strong positive correlation with actual commitment with the purchase of green products. Our results might be used by marketers when approaching the groups similar to our Iranian or Japanese student samples. Green advertising could employ arguments of self-efficacy and social responsibility (because SA and SE have been significant predictors of SC behavior). We hypothesize that employing messages of how an individual consumer acts (e.g., a purchase) meaningfully contributes to solving an environmental problem would have significant effects on SC behavior.

The study presented in this paper has its restrictions and limitations; therefore, the results should be treated as indicative, rather than definitive. The main limitation of the present research is that it is not representative. Though student samples have often been employed in scientific literature for testing some indicative hypothesis and searching for possibly valid trends, wider research with representative samples should follow. For a representative survey of, e.g., the Iranian population, we would suggest including social awareness, self-efficacy and environmental attitudes as predictor variables. Future research should also look for other significant predictors in the case of Iran. Our study is limited to testing a small set of socio-cultural predictors of sustainable consumption. These have been chosen based on previous research and relevance to the studied cases. Further research should expand the search of significant predictors, employing not solely socio-cultural variables, but also situational, social structural and other variables. Finally, it has to be noted that this paper is empirically oriented and therefore limited to only a short overview of main publications in the field. There is already an abundancy of related research and it would be good to conduct an extensive overview, or even to carry out a systematic literature review.

Our findings might have some policy implications. Much focus has been put on educational tools (e.g., introducing the topic of sustainable consumption into school programs) and environmental awareness raising tools (e.g., labeling of products). Yet, as our results prove, knowledge is not the strongest or most consistent determinant of sustainable consumption behavior. Thus, policies should also consider the other soft levers directed at modeling the self-efficacy and social awareness of consumers.

Author Contributions: Conceptualization, A.T.; methodology, S.S., A.T. and Z.P.; formal analysis, S.S. and Z.P.; investigation, S.S. and Z.P.; data curation, S.S. and Z.P.; writing-original draft preparation, S.S., A.T. and Z.P.; writing—review and editing, S.S., A.T. and Z.P.; visualization, S.S., A.T. and Z.P. All authors have read and agreed to the published version of the manuscript.

Funding: This research received no external funding.

Institutional Review Board Statement: Ethical approval was not sought for the study because no binding regulations were established at the researched universities at the moment of data collection. 
Informed Consent Statement: Informed consent was obtained from all subjects involved in the study.

Data Availability Statement: The data presented in this study are available on request from first author Sadegh Salehi.

Acknowledgments: We thank Mikiko Shinoki of Chou University, Japan, for collecting data from Japanese samples.

Conflicts of Interest: The authors declare no conflict of interest.

\section{References}

1. Pawłowski, A. Sustainable Development and Globalization. Probl. Ekorozw. 2013, 8, 5-16.

2. Soltanipour, F.; Damari, B. The Situation of Sustainable Development in Iran. J. Sch. Public Health Inst. Public Health Res. 2017, 14, 1-14.

3. Lim, E.; Arita, S.; Joung, S. Advancing sustainable consumption in Korea and Japan-from re-orientation of consumer behavior to civic actions. Sustainability 2019, 11, 6683. [CrossRef]

4. Hayward, B.; Roy, J. Sustainable Living: Bridging the North-South Divide in Lifestyles and Consumption Debates. Ann. Rev. Environ. Resour. 2019, 44, 157-175. [CrossRef]

5. Kollmuss, A.; Agyeman, J. Environmental Education Research Mind the Gap: Why do people act environmentally and what are the barriers to pro-environmental behavior? Taylor Francis 2010, 8, 239-260. [CrossRef]

6. Stern, P.C. New Environmental Theories: Toward a Coherent Theory of Environmentally Significant Behavior. J. Soc. Issues 2000, 56. [CrossRef]

7. Whitmarsh, L.; O'Neill, S. Green identity, green living? The role of pro-environmental self-identity in determining consistency across diverse pro-environmental behaviours. J. Environ. Psychol. 2010, 30, 305-314. [CrossRef]

8. Liu, Y.; Qu, Y.; Lei, Z.; Jia, H. Understanding the Evolution of Sustainable Consumption Research. Sustain. Dev. 2017, 25, 414-430. [CrossRef]

9. Minton, E.A.; Spielmann, N.; Kahle, L.R.; Kim, C.H. The subjective norms of sustainable consumption: A cross-cultural exploration. J. Bus. Res. 2018, 82, 400-408. [CrossRef]

10. Karimzadeh, S.; Abbaszadeh, M.; Kašparová, E. Incentives and Inhibitors of Sustainable Consumption: A qualitative study among Urmia informants. Pol. Sociol. Rev. 2019, 208, 477-491.

11. Salehi, S. People and the Environment: A Study of Environmental Attitudes and Behavior in Iran; LAP Lambert Academic Publishing: Sunnyvale, CA, USA, 2010.

12. Iran's Ministry of Power. Energy Balance Sheet Of 2015; Iran's Ministry of Power: Tehran, Iran, 2015; p. 6.

13. Presidential Strategic Research Center. Report on the Environment in Iran and the World and Describing of Functions; Strategic Research Institute: Tehran, Iran, 2018.

14. Salehi, S.; Pazokinejad, Z.; Mahmoudi, H.; Knierim, A. Gender, responsible citizenship and global climate change. Women Stud. Int. Forum 2015, 50, 30-36. [CrossRef]

15. Rieckmann, M. Future-oriented higher education: Which key competencies should be fostered through university teaching and learning? Futures 2012, 44, 127-135. [CrossRef]

16. Robinson, J.; Berkhout, T.; Campbell, A. The University as an Agent of Change for Sustainability; Policy Horizons Canada: Toronto, ON, Canada, 2011.

17. Hsu, S.J. The effects of an environmental education program on responsible environmental behavior and associated environmental literacy variables in taiwanese college students. J. Environ. Educ. 2004, 35, 37-48. [CrossRef]

18. Levine, D.S.; Strube, M.J. Environmental attitudes, knowledge, intentions and behaviors among college students. J. Soc. Psychol. 2012, 152, 308-326. [CrossRef]

19. Kilbourne, W.E.; Polonsky, M.J. Environmental Attitudes and their Relation to the Dominant Social Paradigm among University Students in New Zealand and Australia. Australas. Mark. J. 2005, 13, 37-48. [CrossRef]

20. Budak, D.B.; Budak, F.; lu, Z.Z.; Kekec, S.; Sucu, M.Y. Behaviour and Attitudes of Students towards Environmental Issues at Faculty of Agriculture, Turkey. J. Appl. Sci. 2005, 5, 1224-1227. [CrossRef]

21. Spellman, G.; Field, K.; Sinclair, J. Assessing UK higher education students' awareness of global climatic change. Weather 2003, 58, 212-219. [CrossRef]

22. De Carvalho Maffia, A.M.; Silva, E.; Jacovine, L.A.G. Environment and environmental awareness: How university students conceive and act. Acta Sci. Biol. Sci. 2011, 33, 209-214. [CrossRef]

23. Salehi, S.; Pazokinejad, Z.; Mahmoudi, H.; Burkart, S. Knowledge of global climate change: View of Iranian university students. Int. Res. Geogr. Environ. Educ. 2016, 25, 226-243. [CrossRef]

24. Kroll, C. Sustainable Development Goals: Are the Rich Countries Ready? Bertelsmann Stiftung: Gütersloh, Germany, 2015.

25. Iran-Tehran Solid Waste Management Project (English). Project Information Document (PID) Concept Stage; World Bank Group: Washington, DC, USA, 2003; p. 3.

26. Iran Waste Management Organization. Analysis of Process of Waste Management in World and Iran; Iran Waste Management Organization: Teheran, Iran, 2019; p. 4. 
27. Farajzadeh, Z. Energy Intensity in the Iranian Economy: Components and Determinants. Iran. Energy Econ. 2016, 4, 43-86. [CrossRef]

28. United Nations Division for Sustainable Development. Agenda 21—Chapter 4 Changing Consumption Patterns. 1992. Available online: https:/ / sustainabledevelopment.un.org/content/documents/Agenda21.pdf (accessed on 27 January 2019).

29. Alexander, S. Degrowth Implies Voluntary Simplicity: Overcoming Barriers to Sustainable Consumption. SSRN Electron. J. 2012. [CrossRef]

30. Poortinga, W.; Steg, L.; Vlek, C. Environmental risk concern and preferences for energy-saving measures. Environ. Behav. 2002, 34, 455-478. [CrossRef]

31. Chen, X.; Peterson, M.N.; Hull, V.; Lu, C.; Lee, G.D.; Hong, D.; Liu, J. Effects of attitudinal and sociodemographic factors on pro-environmental behaviour in urban China. Environ. Conserv. 2011, 38, 45-52. [CrossRef]

32. Dermody, J.; Hanmer-Lloyd, S.; Koenig-Lewis, N.; Zhao, A.L. Advancing sustainable consumption in the UK and China: The mediating effect of pro-environmental self-identity. J. Mark. Manag. 2015, 31, 1472-1502. [CrossRef]

33. Gilg, A.; Barr, S.; Ford, N. Green consumption or sustainable lifestyles? Identifying the sustainable consumer. Futures 2005, 37, 481-504. [CrossRef]

34. Casimir, G.; Dutilh, C. Sustainability: A gender studies perspective *. Int. J. Consum. Stud. 2003, 27, 316-325. [CrossRef]

35. Harun, R.; Hock, L.K.; Othman, F. Environmental knowledge and attitude among students in Sabah. World Appl. Sci. J. 2011, 14, 83-87.

36. Meinhold, J.L.; Malkus, A.J. Adolescent environmental behaviors: Can knowledge, attitudes and self-efficacy make a difference? Environ. Behav. 2005, 37, 511-532. [CrossRef]

37. Moon, S.G.; Jeong, S.Y.; Choi, Y. Moderating effects of trust on environmentally significant behavior in Korea. Sustainability 2017, 9, 415. [CrossRef]

38. Wells, V.K.; Ponting, C.A.; Peattie, K. Behaviour and climate change: Consumer perceptions of responsibility. J. Mark. Manag. 2011, 27, 808-833. [CrossRef]

39. Kellstedt, P.M.; Zahran, S.; Vedlitz, A. Personal Efficacy, the Information Environment, and Attitudes Toward Global Warming and Climate Change in the United States. Risk Anal. 2008, 28, 113-126. [CrossRef]

40. Salehi, S.; Pazokinejad, Z. Social Trust, Women and Policies Tackling Climate changes. Soc. Stud. Res. Iran 2014, 3, $221-238$.

41. Laurian, L. A prerequisite for participation: Environmental knowledge and what residents know about local toxic sites. J. Plan. Educ. Res. 2003, 22, 257-269. [CrossRef]

42. Prasolova-Førland, E. Supporting Social Awareness among University Students with Collaborative Virtual Environments. Ph.D. Thesis, Norwegian University of Science and Technology, Trondheim, Norway, 2004.

43. Greene, S.R.; Kamimura, M. Ties that Bind: Enhanced Social Awareness Development through Interactions with Diverse Peers; Annual Meeting of the Association for the Study of Higher Education: Portland, Oregon, USA, 2003.

44. Aitken, C.; Chapman, R.; McClure, J. Climate change, powerlessness and the commons dilemma: Assessing New Zealanders' preparedness to act. Glob. Environ. Chang. 2011, 21, 752-760. [CrossRef]

45. Rainear, A.M.; Christensen, J.L. Protection Motivation Theory as an Explanatory Framework for Proenvironmental Behavioral Intentions. Commun. Res. Rep. 2017, 34, 239-248. [CrossRef]

46. Tabernero, C.; Hernández, B. Self-efficacy and intrinsic motivation guiding environmental behavior. Environ. Behav. 2011, 43, 658-675. [CrossRef]

47. Chawla, L.; Cushing, D.F. Education for strategic environmental behavior. Environ. Educ. Res. 2007, 13, 437-452. [CrossRef]

48. Dos Muchangos, L.S.; Vaughter, P. Are gender perspectives included in education for sustainable consumption and waste education programs? A systematic literature review. Detritus 2018, 4, 164-177. [CrossRef]

49. Berger, I.E.; Corbin, R.M. Perceived Consumer Effectiveness and Faith in Others as Moderators of Environmentally Responsible Behaviors. J. Public Policy Mark. 1992, 11, 79-89. [CrossRef]

50. Müderrisolu, H.; Altanlar, A. Attitudes and behaviors of undergraduate students toward environmental issues. Int. J. Environ. Sci. Technol. 2011, 8, 159-168. [CrossRef]

51. Dunlap, R.E.; Van Liere, K.D.; Mertig, A.G.; Jones, R.E. Measuring endorsement of the new ecological paradigm: A revised NEP scale. J. Soc. Issues 2000, 56, 425-442. [CrossRef]

52. Leiserowitz, A.; Smith, N.; Marlon, J.R. American Teens' Knowledge of Climate Change; Yale University: Yale Project on Climate Change Communication 5: New Haven, CT, USA, 2011; p. 63. Available online: https:/ / www.ourenergypolicy.org (accessed on 2 May 2020).

53. Hess, A.K.; Samuel, R.; Burger, P. Informing a social practice theory framework with social-psychological factors for analyzing routinized energy consumption: A multivariate analysis of three practices. Energy Res. Soc. Sci. 2018, 46, 183-193. [CrossRef]

54. Chekima, B.C.; Wafa, S.A.W.S.K.; Igau, O.A.; Chekima, S.; Sondoh, S.L. Examining green consumerism motivational drivers: Does premium price and demographics matter to green purchasing? J. Clean. Prod. 2016, 112, 3436-3450. [CrossRef]

55. Hanss, D.; Böhm, G. Can I make a difference? The role of general and domain-specific self-efficacy in sustainable consumption decisions. Explain. Sustain. Consum. Find. Cross Sect. Interv. Approaches 2010, 14, 46-74.

56. Phipps, M.; Ozanne, L.K.; Luchs, M.G.; Subrahmanyan, S.; Kapitan, S.; Catlin, J.R.; Gau, R.; Naylor, R.W.; Rose, R.L.; Simpson, B.; et al. Understanding the inherent complexity of sustainable consumption: A social cognitive framework. J. Bus. Res. 2013, 66, 1227-1234. [CrossRef] 
57. Kong, N.; Salzmann, O.; Steger, U.; Ionescu-Somers, A. Moving Business/Industry towards Sustainable Consumption: The Role of NGOs. Eur. Manag. J. 2002, 20, 109-127. [CrossRef]

58. Mont, O.; Bleischwitz, R. Sustainable consumption and resource management in the light of life cycle thinking. Eur. Environ. 2007, 17, 59-76. [CrossRef]

59. Osman, A.; Jusoh, M.S.; Amlus, M.H.; Khotob, N. Exploring the relationship between environmental knowledge and environmental attitude towards pro-environmental behaviour: Undergraduate business students perspective. Am. Eurasian J. Sustain. Agric. 2014, 8, 1-7.

60. McCright, A.M. The effects of gender on climate change knowledge and concern in the American public. Popul. Environ. 2010, 32, 66-87. [CrossRef]

61. Kaiser, F.G.; Wölfing, S.; Fuhrer, U. Environmental attitude and ecological behaviour. J. Environ. Psychol. 1999, 19, 1-19. [CrossRef]

62. Nguyen, H.V.; Nguyen, C.H.; Hoang, T.T.B. Green consumption: Closing the intention-behavior gap. Wiley Online Libr. 2018, 27, 118-129. [CrossRef]

63. Failla, J.; Gopalakrishna, P. Moderator role in green product purchases. Atl. Mark. J. 2014, 3, 14-22. 